\title{
Archipel
}

ARCHIPEL Études interdisciplinaires sur le monde insulindien

$97 \mid 2019$

Varia

\section{Pangolin, Rāma, and the garden in Lankā in the 9th century CE : A few notes on a symbolically powerful "anteater"}

Pangolin, Rāma, et le jardin de Lañkā au IX $X^{e}$ siècle EC : Quelques notes sur un « mangeur de fourmis » symboliquement puissant

\section{Jiří Jákl}

\section{OpenEdition}

Journals

\section{Electronic version}

URL: https://journals.openedition.org/archipel/1030

DOI: $10.4000 /$ archipel. 1030

ISSN: 2104-3655

\section{Publisher}

Association Archipel

\section{Printed version}

Date of publication: 11 June 2019

Number of pages: $69-86$

ISBN: 978-2-910513-81-8

ISSN: 0044-8613

\section{Electronic reference}

Jiří Jákl, "Pangolin, Rāma, and the garden in Laǹkā in the 9th century CE : A few notes on a symbolically powerful "anteater" ", Archipel [Online], 97 | 2019, Online since 16 June 2019, connection on 15 September 2021. URL: http://journals.openedition.org/archipel/1030 ; DOI: https://doi.org/ 10.4000/archipel. 1030 
$J_{I \check{R} I J} J_{A K L^{l}}$

\section{Pangolin, Rāma, and the garden in Lankā in the 9th century CE: A few notes on a symbolically powerful "anteater"}

\section{Introduction}

The Sunda pangolin (Manis javanica), also known as the Javan pangolin, features in four closely related passages in the Kakawin Rämāyana, a poem composed between the second half of the 9th and the first quarter of the 10th century $\mathrm{CE}$ in the court register of Old Javanese. ${ }^{2}$ A visual representation of a pangolin also figures in an enigmatic narrative relief on Candi Śiwa, the major temple in the Prambanan complex, and a very large skeleton of a pangolin was found interred under the Candi Nandi located just in front of the Siwa temple. Inspired by a pioneering essay on the topic by Mary-Louise Totton (2011), this article tries to make sense of this sparse but significant evidence, and offers new reading of several Old Javanese textual passages.

For readers unacquainted with this remarkable animal, a few notes about its biology might help them to understand the major argument advanced in this article more clearly. The pangolin is a mammal native to Southeast Asia, and the Sunda pangolin used to be common throughout Java in the past. It prefers forested habitat, and spends a large part of its life in trees. ${ }^{3}$ Uniquely

1. Heidelberg University, Institute of Anthropology, jiri.jakl@uni-heidelberg.de.

2. I would like to thank Véronique Degroot for a number of valuable comments on the first draft of this paper. The comments helped substantially to improve the arguments advanced in this article. I am also grateful to Mrs Rosemary Robson, for correcting my English.

3. The Sunda pangolin is closely related to the Chinese pangolin, but the Indonesian 
among mammals, its body is covered with rows of keratin scales. Also quite exceptionally among the mammals found in Southeast Asia, its diet is based almost completely on ants and termites: the pangolin has powerful claws allowing it to dig into the soil in search of ants' nests or to break into termite mounds. The pangolin has poor eyesight but a very acute sense of smell. Typically pangolins are solitary, nocturnal animals. Despite its appearance, the pangolin is not aggressive, and when facing danger the animal rattles its scales, sprays a foul scent, and lashes its sharp scaly tail (Schlitter 2005: 532). Pangolins have few natural enemies, mostly tigers and other big cats. ${ }^{4}$ When threatened by a formidable predator like a leopard, the pangolin protects its soft belly by rolling into a ball. Pangolins make burrows near termite mounds and ants' nests, and, traditionally, termite mounds were taken as markers of the nearby presence of pangolins.

In modern Javanese, the pangolin called tingilin in Old Javanese, is tenggiling. ${ }^{5}$ Scholars of Old Javanese literature, however, often translate tingilin rather imprecisely as "anteater." This could be potentially misleading, for anteater is a name reserved for the four mammal species of the suborder Vermilingua, animals commonly known for eating ants and termites but which are native to South America and were not found in Java in the past. ${ }^{7}$ In popular use, today the pangolin is sometimes called "scaly anteater." Although the pangolin is only rarely mentioned in Old Javanese literature, this animal does figure prominently in the Kakawin Rämāyana, the earliest extant specimen of the kakawin literary genre. ${ }^{8}$ In this Old Javanese version of the Rämāyana story, the pangolin is mentioned in four passages, in three of which it figures alongside another remarkable mammal commonly found in Java, the porcupine. Intriguingly, as mentioned the skeleton of a very large pangolin was found interred beneath the Canḍi Nandi, a temple dedicated to the bull-mount of Śiva, in the Loro Jonggrang temple complex at Prambanan. The pangolin was interred in a

species is larger, lighter in colour, and has shorter fore-paws (Schlitter 2005).

4. Today, pangolins are among the most severely poached and exploited animals, hunted for their skin, scales, and meat. Illegal international trade, largely driven by Chinese buyers, has led to rapidly decreasing population numbers, and the Sunda pangolin is currently among the critically endangered species.

5. For tenggiling in Modern Javanese, see Robson and Singgih Wibisono (2002: 737).

6. See, for example, Robson (2015: 736).

7. Colloquially, however, the term "anteater" is applied to the unrelated pangolins, as well as numbats, echidnas, and some other mammals for which ants are an important part of their diet. At one time, because of their physical similarities anteaters were assumed to be related to pangolins, but these similar features have since been explained as a sign of convergent evolution (Schlitter 2005: 532).

8. Kakawin is a metrical poem composed in the literary register of Old Javanese. Kakawins were written in Java between the 9th to 15 th century CE, and later also in Bali (Zoetmulder 1974). 
specially constructed shaft, almost six metres below the Nandi statue, alongside the remains (mostly teeth) of one or more porcupines (Ijzerman 1891: 67). Canḍi Nandi faces the central Candi Śiwa and, as Totton (2011: 11) notes, "the placement of pangolin in the brick-lined shaft under the centre wahana candi denotes its superior status, just as Siwa outranks Wisnu and Brahma, who flank him in smaller candi." This ritual use of the pangolin is interesting and deserves closer attention in view of the apparent symbolic meanings of the pangolin in the Kakawin Rāmāyana, a text composed in the same social milieu in which Prambanan functioned as the major religious complex.

\section{Pangolin, demonic ants, and military figures in 9th-century Java}

In the past the scaly skin of the pangolin was used for the personal protection of warriors, and several specimens of this sort of armor are known in European collections. For example, an impressive cuirass made from the skin of a pangolin was acquired by a French traveller at the end of the 17th century CE, probably in Borneo, and it is now preserved in the Musée du Quai Branly in Paris (for former location, see Léger 1979). However, no actual specimen of pangolin armor from Java has been documented. Given this data it is not surprising that the pangolin is represented in the Kakawin Rāmāyāna, a text which can be read as a political allegory, as a military figure. In sarga 25 , the anonymous author describes Rāma and Sītā on their way back to Ayodhyā, aboard the airborne vehicle Puspaka. They are delighted with the countryside seen from the air and, as they approach Rāma's native Ayodhyā, the hero is moved when he sees (and smells!) the well-known tracts of his homeland. After having been away for many years, Rāma describes to Sìtā the natural beauties of his beloved home, marked by "local" plants and inhabited by typically Javanese animals, as described in stanza 25.101:

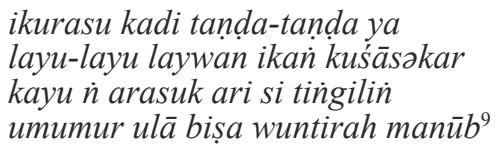

The $i_{k u r a s u}{ }^{10}$ resembles war standards,

And the kuśa grass ${ }^{11}$ in flower is the pennants;

Trees, the warriors in armour, are younger brothers of the pangolin -

Quickly slips away the poisonous snake when the flying-fox swoops down. ${ }^{12}$

9. Kakawin Rāmāyana 25.101. Old Javanese text taken from Van der Molen (2015: 595). 10. The actual referent of Old Javanese ikarasu is not entirely clear. The literary meaning of the word, "dog's tail," seems to point to a species of wild grass.

11. Old Javanese kuśa, a loanword from Sanskrit, denotes a perennial grass known in Europe as Halfa grass or salt reedgrass (Desmostachya bipinnata). This plant was extremely important in Hindu and Buddhist ritual in South and Southeast Asia. Sitting mats were often woven from kuśa grass.

12. Soewito Santoso (1980: 701) translates this stanza: “The ikur-asu (loosestrife) 
Although situated in the mythical time-space of the epic Ayodhyā, the scene, part of the description of Ràma's homeland, is mapped onto the Javanese landscape; in fact, the whole of stanza 25 of the Kakawin Ràmāyana abounds in descriptions of the local flora and fauna and is hence a treasure-trove of Old Javanese plant and animal names. ${ }^{13}$ In stanza 25.98, Rāma's feelings on his arrival home are described in these words: "Even when he has seen all the countries of other people, when he gets home his heart moves." 14 Interestingly, local plants and animals are envisioned as an imaginary army, or armed troops. Despite the fact that the motif of plants imagined as war banners is common in the Old Javanese martial imagination, the trio of a pangolin, snake, and wuntirah represents a unique image. The wuntirah is the Old Javanese term for the greater flying fox (Pteropus vampyrus), an impressively large bat also known as the Malayan flying fox or large fruit bat. It is one of the largest bats and its wingspan can reach $1.5 \mathrm{~m} .{ }^{15}$ The greater flying fox feeds exclusively on flowers, nectar, and fruits (Simmons 2005: 345). Most interesting, however, is the allegorical reference to the pangolin, an animal famous for its scaly skin, and in this stanza likened to the "armoured trees" (kayu $\dot{n}$ arasuk). ${ }^{16}$ Old Javanese rasuk denotes "dress, attire; mail" (Zoetmulder 1982: 1518), and we can be certain that "armour, mail" is the intended meaning in the passage quoted above because the whole of stanza 25.101 is based on a martial metaphor. But what are the "armoured trees" (kayu $\dot{n}$ arasuk) that are taken to be typical of the Javanese environment? One possible explanation is that they represent majestic kapok trees, known not only for their large size but especially for their sharp thorns that protect the trees from leaf-eating predator pests, like monkeys. Hence these thorns function as a kind of "armour" for the trees. ${ }^{17}$ One famous passage in the Kakawin Rāmāyana in which kapok trees

is like a banner, the flag is the flower of the tall grass. The banyan-tree acts like the anteater which drives away a venomous snake swooping down on a flying fox."

13. See the two stanzas preceding the stanza 25.101 quoted above; in just two stanzas (25.99 and 25.100) at least twelve plant species are mentioned, some of them, like acun-acun and wyah, represent swamp plants used as locally well-known food plants.

14. Robson (2015: 736).

15. As with all mega-bats, it has a fox-like face, hence its name. Unlike most bats, fruit bats have a well-developed eyesight (Simmons 2005: 346).

16. Soewito Santoso (1980: 701), for one, renders kayu in this stanza as "banyan," which fails to convince me. My interpretation of this line also differs from the translation advanced by Robson (2015: 736), who renders the third line of stanza 25.101: "There is one in armour, my dear, the anteater."

17. Véronique Degroot has suggested that this is not the only option. Other possible candidates would be ulin wood, known for its hardness, and teak wood, from which shields and helmets were made in the past. Both tree species are indeed loaded with the martial symbolism and represent alternative interpretations for the enigmatic "armoured trees." 


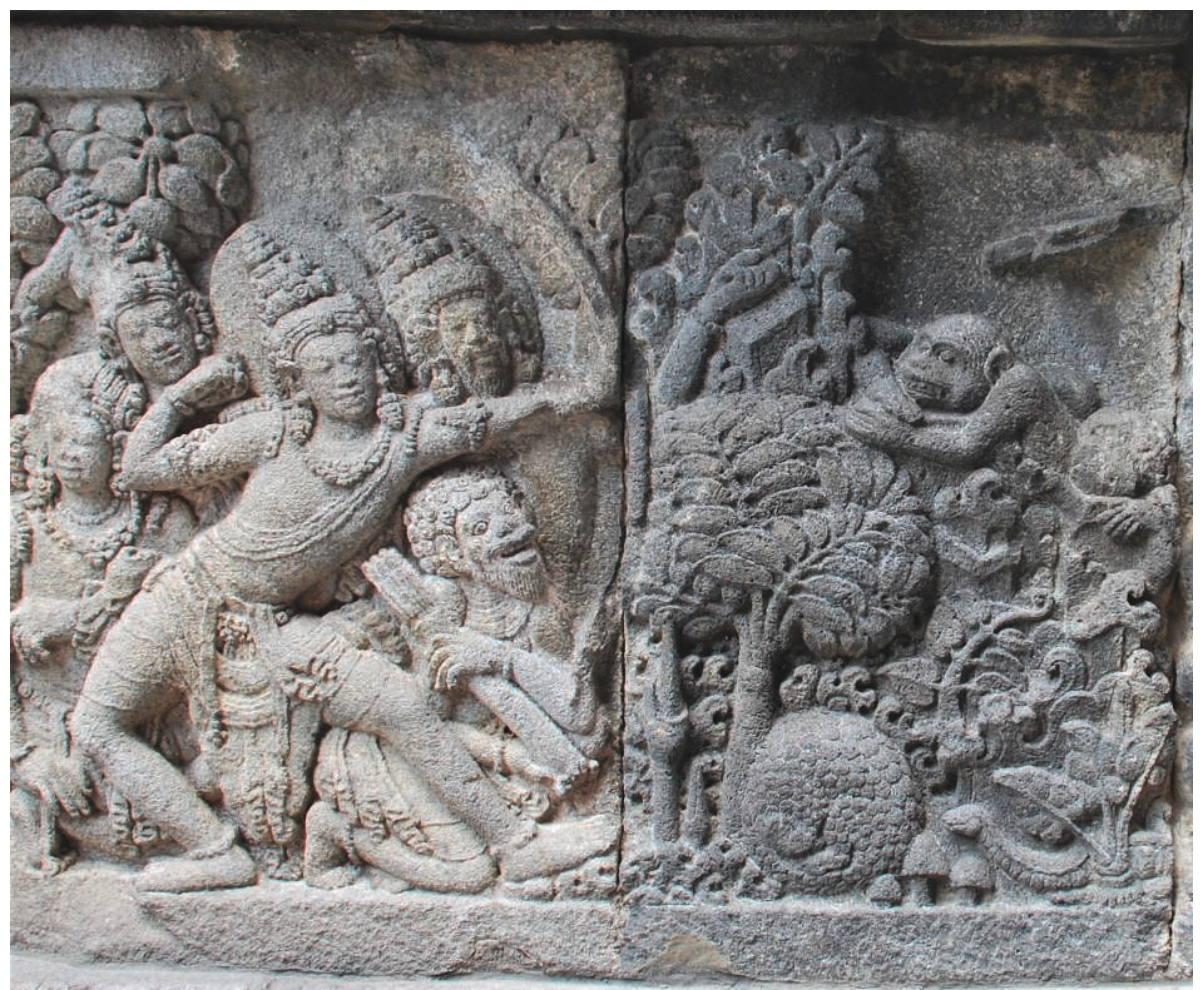

Fig. 1 - Caṇdi Śiwa relief at Prambanan showing a pangolin (bottom, to the right). Credit: Véronique Degroot.

figure is stanza 22.51: simian soldiers, trying to save themselves from the rampaging of the rākșasa giant Kumbhakarna, climb kapoks. Unsurprisingly, the humanized trees, offended by cowardly behavior of the simian soldiers, shake sending the scared monkeys tumbling down. Immediately afterward, the simian soldiers climb sugar palms, another plant famous for its thorns. ${ }^{18}$ Pertinently, lines $c$ and $d$ in the passage quoted above are closely related and should be read as a semantic unit. Kapok trees, with their spreading crowns, often host fruit bats, like flying foxes, and in line $d$ we do indeed learn that the "flying fox swoops down": it is from the tree crown, the place where it roosts, that it flies down.

A similar forest environment represented by the Javanese flora and fauna, depicted on the narrative relief on Candi Siwa in the Loro Jonggrang temple complex at Prambanan, features a pangolin that is shown in a defensive

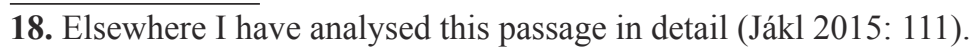


posture. Totton (2011: 16) has rightly observed that the insertion of the pangolin encodes "information with local visual clues." On the left of the scene we see Rāma who has just loosed an arrow from the large bow of Wiṣnu. Several figures crowd around him: we can identify his brother, Lakșmana, and probably Paraśurāma, among them. The arrow has flown over the expanse of forest in front of him, landing on the roof of the residence of Daśaratha, Rāma's father, in Ayodhyā. ${ }^{19}$ The scene has been identified as Rāma and Sìtā heading to meet Daśa ratha in Ayodhyā, after Rāma had won the hand of Sìtā in the archery contest. From the Rāmāyaña we know that, on their way, they are halted by Paraśurāma, who is forced to acknowledge Rāma's superior power as a new avatār of Viṣnu. ${ }^{20}$ The setting is that of a jungle, therefore only wild plants, animals, and - quite uniquely - mushrooms, are represented on the relief; a small snake emerging from its hole, as well as pangolins and monkeys all help to indicate that the scene is set in a densely wooded environment. Totton (2011: 18) observes that the pangolin 'curls before Rama, acting as a submissive devotee who offers a warning and a strategy of surviving: wait out the danger ahead.' I find this explanation interesting, especially in view of the fact that Paraśurāma, too, offers Rāma his homage in the same scene. Nevertheless, I cannot subscribe to the view that the pangolin is represented in this scene as a devotee of Rāma; for pangolins, curling themselves up is not an act of submission, but rather an act of self-defense and resistance. Moreover, my interpretation of the symbolic value of this animal in ancient Java differs from that advanced by Totton, which will emerge more clearly below. Before offering my understanding of the symbolic meanings ascribed to the pangolin in Old Javanese texts, I want to discuss yet another interesting aspect of the enigmatic scene on the narrative relief on the Loro Jonggrang, one that adds to what is obviously the very complex symbolism of pangolin in ancient Java.

Unique among the Javanese temple reliefs is a depiction of a cluster of three mushrooms, alongside the amorpho-phallus plant Amorphus variabilis. Totton (2011: 17) has suggested that the mushrooms "have the form and dotted cap as the bright red and white fungi, Amonita muscaria, hallucinatory mushrooms thought by many to be the primary component of soma, the elixir of immortality associated with Siwa and Tantric spiritual alchemy." This identification, however, is purely speculative. Totton (2011: 17) has also claimed that the presence of mushrooms "helps place the scene in the forest." However, it is a well-known fact that mushrooms are relatively rare in tropical

19. In the next scene, we see Rāma's father and Kaikeȳi, his crafty third wife, who forces the king to put Bharata, her own son, on the throne instead of Rāma (Totton 2011: 18).

20. Paraśurāma had previously cleansed the world of the warrior caste 21 times. Daśaratha, Rāma's farther, only survived because he bowed before Paraśurāma (for details of this story, see especially Hiltebeitel 2001). 
rainforests; therefore it is pretty improbable that the sculptor would have depicted them as typical, or representative of the densely wooded habitat, as suggested by Totton. In my view, far more persuasive is the view expressed a long time ago by Cammerloher (1934: 202), who tentatively identified the three mushrooms as "termite mushrooms" (Agaricales), known in modern Javanese as jamur rayap, and in modern Sundanese as supa bulan. ${ }^{21}$ As their scientific name suggests, termitomyces are a food source for termites: the fungi grow on "combs" that are formed from by the termites' excreta, in which tough wood fragments predominate. ${ }^{22}$ It seems to me that, by including these mushrooms in the scene, the Javanese sculptor was indicating the presence of termites, and, the pangolins that fed on them. Hence Rāma is shooting his arrow literally over the termite nest or mound. The presence of Paraśurāma, a brahman warrior who cleansed the world of the warrior caste many times, is also significant: in the next scene, as we have already seen above, Rāma's arrow lands on the roof of his father's residence in Ayodhyā, foretelling the doom of Daśaratha who, bamboozled by his wife Kaykeȳ̄, had expelled his own son into wilderness.

In pre-modern Java, the pangolin was accorded a liminal status. Totton (2011: 14) has observed that "its scales associate it with fish and reptiles, its long claws are like an eagle's or tiger's (not to mention that long nails are an attribute of royal figures), and a pangolin can appear to mimic humans (its twolegged gait and so-called courtly behaviour of bowing its head)." However, none of these characteristics is crucial to understanding the very special status of the pangolin in ancient Java. In my view, to comprehend the symbolism of the pangolin in ancient Java fully, we must understand the very specific symbolism ascribed to its diet. As we have seen above, the pangolin sustains itself almost exclusively with ants and termites, which it daily consumes in immense numbers. Therefore the animal can only thrive in areas in which large populations of termites and ants are found. Now, in ancient Java ants and termites were symbolically loaded insects. Elsewhere I have demonstrated the complex symbolic meanings of the swarming and mating flights of ants and termites, and the "digestion" of the śakti of one's enemies, a process prominently symbolized by these insects, as this is documented in Old Javanese literature (Jákl 2012). ${ }^{23}$ To summarize briefly, the image of swarming ants/

21. Elsewhere, however, Cammerloher (1934: 203) has identified the mushrooms as Gymnopus albuminosus.

22. It should be noted, however, that not all mushrooms of the order Agaricales are "termite fungi." I am grateful to one of my anonymous reviewers for this suggestion.

23. Ants and termites, as is well-known, are gregarious, social insects, living in highly organized, hierarchical colonies, each colony found on the coexistence of two separate castes. At certain periods, the queens fly away from their nests in order to establish new colonies. During their mating flights, queens mate with numerous male ants. 
termites falling into a fire or onto an open lamp was used almost exclusively in war passages of kakawins and kiduins to allude to the forces of fate presiding over the epical (and real) warfare. The locally well-known propensity of swarming ants to fly headlong into a fire, to die consumed by its flames, was used by Javanese poets to allude to desperate attacks of warriors doomed to failure, their śakti "consumed" by the superior śakti of their opponents. In the framework of pre-Islamic views, the pangolin is a model warrior, literally "eating up" the śakti of (demonic) enemies. Furthermore, we should not underestimate the belief in the efficacy of notions based on sympathetic magic in pre-modern Java; we have substantial evidence that sympathetic magic was commonly used in the context of warfare in Java, and in other parts of ancient Indo-Malay world (Quaritch Wales 1952; Charney 2004). Importantly for our discussion, warriors symbolized by burnt ants/termites were always classified as demons (like asuras, yakșas, niśācaras) or human warriors fighting for adharma (in particular: the Korawas). Hence, for the pre-modern Javanese, the pangolin's śakti was particularly strong as it "attracted" innumerable ants and termites to be literally consumed by the pangolin and their śakti 'digested' in the process of pangolin's feeding. In my view, the belief in the magical powers of the pangolin as a "consumer" of demonic śakti - associated with ants and termites - was crucial to its interment in the Candi Nandi in the Prambanan temple complex. It is the apotropaic, protective status of the pangolin that was prominent in ancient Java. In the next section, we shall see that the pangolin is represented as a warrior who guards Rāwaṇa's pleasure garden in Lañkā in the Kakawin Rāmāyaṇa. Now, a number of scholars have suggested that Rāwaña be identified with a Śailendra king and Rāwana's epic court (and hence also his pleasure garden) of Lankā with the Ratu Boko hillock in Central Java, a place once the site of the Buddhist monastery of the Abhayagirivāsins, founded by a Śailendra king in 792 CE. After the initial defeat of the Buddhist Śailendras in $856 \mathrm{CE}$, Ratu Baka was converted into a Śaiwa complex by the enigmatic man known in Old Javanese inscriptions by the name Kumbhayoni, and revitalized as an important pilgrimage site. An expansive garden had already been envisaged on the plateau by Bernet Kempers in 1978, but archeological research is needed to confirm or disprove this idea. ${ }^{24}$ Although considerable scholarly attention has been devoted to Ratu Baka in the last twenty years, we still know too little about the origins and history of this site. In particular, we know very little about the sojourn of Abhayagirivāsins on Ratu Baka. Sundberg (2016: 361) notes that, "no piece of evidence on the plateau sheds light on the

In that season these winged males, air-borne for a short mating period, form large swarms of flying ants.

24. The status and function of Ratu Boko has been discussed by a number of scholars (for review of the evidence, see especially Degroot 2006; Miksic and Slamet Pinardi 2015). It has been suggested that the place was a Buddhist monastery, royal palace, or both. 
Abhayagiri and its monastic denizens in the years between its founding in ca. 792 and the year AD 856." Unquestionably, Ratu Baka is unique among the sites in Central Java: a significant number of Chinese ceramics found on the plateau indicates that the site was occupied, or visited, from the 11th to 13 th centuries CE, while the amount of ceramics decreased significantly in the 14th century CE. Degroot (2006: 69) observes that such a long period of occupation is attested to at only one other Central Javanese site, the Dieng Plateau, that was an important place of pilgrimage. One cannot help but make a comparison with the similar pattern/ground-plan documented from Sigiriya in Sri Lanka, a pilgrimage site famous for its expansive and very complex ancient garden: after the 13 th or 14 th century $\mathrm{CE}$, the place was almost completely abandoned (Bopearachchi 2006; Cooray 2012: 62). The presence of a large garden on Ratu Baka, that served as an important pilgrimage site even before Abhayavihārins occupied the place (Griffiths 2013: 75), ${ }^{25}$ would at least partially explain why a vast expanse of the plateau seems to be devoid of any traces of architecture and habitation. Yet, the present form of the Ratu Baka Plateau is a man-made structure. Sundberg (2004: 101) observes that the landscaping design on Ratu Baka is "an immense civil engineering project including clearing, quarrying, excavating, and filling up the natural hill and refashioning it as a flat, manicured, terraced, and walkwayed plateau." Degroot (2006: 71) has tentatively suggested that Ratu Baka might have been used, among other functions, to protect the royal palladium of Mataram. An expansive royal garden that would accommodate the palladium (of Śailendras before $856 \mathrm{CE}$, and of Mataram after $856 \mathrm{CE}$ ), and serve as a pilgrimage site would indeed explain the result of a large-scale engineering project that would leave little traces of architecture and habitation.

Returning to stanza 25.101 quoted above, the text seems to suggest that the pangolin, once a protector of Rāwaṇa's pleasure garden, metamorphized into an apotropaic figure around the time of Rāma's flight to Ayodhyā. Recently, Griffiths (2011: 147-48) has offered a hypothesis that the ancient toponym "Lankapura," attested in a group of inscriptions associated with the Ratu Boko area and that he has dubbed the "Kumbhayoni Corpus," refers to the ancient wanua (settlement) corresponding to the modern village of Karangasem,

\footnotetext{
25. Griffiths (2013: 75) has proposed that Abhayagiri was known as such even before the Abhayagirivāsins established their monastery there, postulating the hypothesis that Satyavarman of Pāndurañga in Campā undertook the erection of the Buddhalokeśvara image there, in order "to engage in diplomacy with the expansive Śailendra rulers, to persuade them to leave mainland Southeast Asia in peace." The long pilgrimage and diplomatic mission of Satyavarman from Campā to Java, possibly to the Sailendra court and to Ratu Baka, was not a solitary historical event. Griffiths (2013: 75, n. 89) offers intriguing evidence from the Campā inscription C. 149, from which we learn that a Cham aristocrat undertook no fewer than two siddhayatrā pilgrimages from Campā to Yavadvīpa, that must mean Java.
} 
in which the Prambanan temple complex is situated, or even to the temple complex itself. The Śiwa temple in this complex features, as we have already seen, an interesting depiction of a pangolin in its narrative program: the pangolin curled in self-defense, that is, in an apotropaic gesture, before Rāma at the moment he has won Sìtā, but is still to be banished to the wilderness by Daśaratha, his father. The self-defensive pangolin could have been used to mark the very site - rejuvenated Lankkapura - at which Javanese kings built the Prambanan complex for the people of that time. Going by what we see on this relief, the place would have been located on the way between the birthplaces of epic Sītā and Rāma, the royal courts of Widarbha and Ayodhyā, places allegorically identified with the local royal dynasties and their seats in ancient Java. On a symbolical level, the garden of Lankā (and its protective pangolins), initially located on the Ratu Boko hillock, has been moved to the precincts of Prambanan, the new spiritual center of ancient Mataram.

\section{Pangolin and porcupine: complementary opposites?}

In three other passages in the Kakawin Rāmāyana in which pangolin figures, it is invariably accompanied by the porcupine. The first time they appear together is in stanza 9.57. The passage is part of the description of Hanumān's heroic feats in Lankā, that include the complete destruction of the pleasure garden of the demon king Rāwana. After slaying the mighty demon Akșa, Hanumān proceeds to smash the fabulous parijāta trees in the garden, an act that throws all the animals living there into tumult. Among the animals and birds so disturbed, a pangolin (tingilin), well-protected by its scaly armour, seems to be undeterred by Hanumān's devastating attack. It does not try to escape but bolts into the undergrowth where it would 'wait out' the attack in hiding. As has already been noted, pangolins spend much of their time in trees, and, in my view, the pangolin in question had just been forced to descend from one of the parijāta tree destroyed by Hanumān. ${ }^{26}$ In the undergrowth the pangolin encounters a porcupine (landak) - the only other animal that seems to have been undeterred by Hanumān's attack - that is trying to copulate with its mate.

sarabha sarabhasan mosat śíghra lunhhā milu $\dot{n}$ tingilin tann iluñ tan logö niścayāpan subaddhānrasuk rìn sukst hewa rin landak amrih makundan priyā

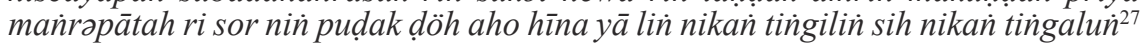

26. From a practical point of view, pangolins were certainly welcome in large garden complexes in ancient Java, from which they would eradicate ants and termites, common pests of gardens. Nocturnal animals, it is easy to understand why in the Kakawin Ramanyana the pangolin is considered the 'armed soldier', the protector of the garden.

27. Kakawin Rāmāyana 9.57c. Old Javanese text taken from Van der Molen (2015: 210). Robson (2015), rather surprisingly, renders tingalü "porcupine," and identifies 
The śarabha deer ran off impetuously and swiftly set off with them, but the pangolin, undaunted, did not follow, because, protected by his mail he felt confident in the grass. Cross with the porcupine who was endeavouring to get together with its mistress, crouching under the leaves of pandanus: "Oh, how low", the pangolin said, "is the "love of the civet cats'."

Among the animals inhabiting the pleasure garden in Lankā, four species are selected for specification: serpents (mentioned in stanza 25.101 quoted above), deer (śarabha), pangolin, and porcupine. In my view, this preference reflects the description in Vālmīki's Rāmāyaṇa, from which we learn that "great serpents and deer" (mahoragavyālamrgā) try to evacuate the garden destroyed by Hanumān (Goldman and Sutherland Goldman 2007: 227). The Javanese poet has introduced the pangolin and the porcupine as interesting additions Moreover, the poet introduces a specific bonding between the pangolin and porcupine. In Old Javanese literature, the porcupine is one of the several animals that is particularly associated with military service and warfare, and it is plausible that, in the passage quoted above, the male porcupine represents a military figure. As noted by Totton (2011: 23), the porcupine is considered "the complimentary opposite of the pangolin - one with dangerous quills and the other with impenetrable scales." It is almost certain that the animal called landak in Old Javanese is identical to the Sunda porcupine (Hystrix javanica), a species endemic to Indonesia. ${ }^{28}$ Sumatra in particular was well-known for its export of civet musk ("civet") in the period under study. Perret (2009: 610), who has collected data on the trade and export of civet musk from ancient Sumatra, calls attention to the Tamil inscription from Lobu Tua, issued in 1088 $\mathrm{CE}$, in which civet is mentioned as part of the taxes paid by traders. Porcupines are rodent-like mammals with a coat of sharp spines (quills) that protect them from predators. They are large, slow terrestrial rodents (Woods and Kilpatrick 2005). Mostly herbivores, Indonesian porcupines are strictly nocturnal, and this habit has certainly had influence on the symbolic representations of these animals in Old Javanese lore. In fact, the porcupine's night-time activities were proverbial in Java: in Old Javanese, the verb form mailandak means 'to work the whole night through' (Zoetmulder 1982: 974).

Totton (2011: 18) gives a different interpretation of the passage quoted above. She observes that "The scaly anteater just ducks under the bush where he knows his wife is hiding. But to his horror, he finds a porcupine trying to rape her. The pangolin leaves the forest in disgust, complaining to itself." The

it with landak. Old Javanese tingalun, however, denotes "civet cat," and it is already glossed as such by Zoetmulder (1982: 2015).

28. Apart from the Sunda porcupine, two other species are found in Indonesia: the Sumatran porcupine (Hystrix sumatrae) and the Malayan porcupine (Hystrix btachyura); these three Indonesian species belong to the group of 11 porcupine species known from the Old World (Woods and Kilpatrick 2005). 
text, however, says next to nothing about a she-pangolin, nor does the poet say anything about a "rape." The porcupine's sexual partner is denoted as kundan in the text: the term used in other Old Javanese kakawins for a "bed-mate," or "mistress," as aptly translated in this particular context in the Kakawin Rämāyana by Robson (2015). ${ }^{29}$ What seems to have horrified the pangolin is the fact that in the situation of imminent danger, the he-porcupine - standing here for a military figure, a soldier - tries to make love to a she-porcupine, qualified by the term kundan a prostitute, or a mistress, who engages in an act called sih nin tingalun. In his recent translation of the Kakawin Rämāyana, rather surprisingly, Robson (2015) ignores the fact that all manuscripts he has used read tingalun, and translates the word as "porcupine." The consistent use of tingalun in the manuscripts, however, suggests that a type of civet is meant; Zoetmulder (1982: 2015), for one, glosses tingalun "civet-cat." 30 I propose the hypothesis that the phrase sih nikan tingalun ("love of the civetcats"), as a reference in the passage quoted above to porcupines' lovemaking, could well have been an Old Javanese euphemism for free, pre-marital sex, or, possibly, for prostitution and venal sex. The Asian palm civet (Paradoxus hermaphroditus), commonly called civet-cat, is notorious for its nocturnal activities (Wozencraft 2005: 534-36). Probably even more importantly in the context discussed here, since at least the 8th century CE civets were exploited for their musk, a strong-smelling secretion from a pouch located under their tails, that was used in perfumery; in Sanskrit literature especially, "courtesans" - basically high-earning prostitutes - were typically associated with the cunning use of musk and other odoriferous substances (McHugh 2012b). ${ }^{31}$ All these characteristics could have marked the civet as a symbolic animal, and resulted in its association with free love/venal sex. Associations between civet-cats and eroticism were well-known in ancient Java. Elsewhere I have demonstrated that there seems to have been a special practical and symbolic bond between palm civets, sugar palms (Arenga saccharifera), and divine temptresses: heavenly nymphs (apsaras) whose literary image in Old Javanese literature is completely based on high-class prostitutes attached to and pimped by Javanese

29. In an article on prostitution in pre-Islamic Java that I am currently preparing, that Old Javanese kundan can be traced to Tamil, and initially denoted a type of prostitute, or mistress.

30. Robson and Singgih Wibisono (2002)

31. In its raw state, the civet, also called civet musk, is foul-smelling and it needs extensive preparation in order to make it into a pleasant perfume. Studying the use of musk and other odoriferous substances in ancient and medieval India, McHugh (2012b: 264) has offered the hypothesis that musk, popular in India from the Gupta period and well established in the classical textual culture, most likely set the precedent for the use of other musk-like materials, including civet. McHugh (2012b: 265) calls civet/ musk a "cosmopolitan vernacular perfume," and suggests that its source in medieval India could have been the Malayan civet (Viverra tangalunga). 
courts, a practice still documented in the 19th century CE from colonial Bali. In the Arjunawiwāha, for example, civet-cats, denoted by a Sanskrit loanword satwa kasturi, are closely associated with the sugar palms, trees that serve as the destinations of imaginary flyways used by heavenly nymphs to descend from Indra's heaven to the earth to tempt ascetics (Ják1 2015: 98).

Unlike pangolins, in ancient Java civets and porcupines seem to have been animals symbolically marked as representing free sex and promiscuity. This finding is further supported by another passage in the Kakawin Rāmāyana: in a famous passage describing an encounter between Lakșmana and the demoness Śūrpanakhā, the sister of Rāwaṇa, who is allegorically endowed with the physical attributes of the porcupine. Stricken with passion on seeing young Lakșmana, she adopts the gait of a noble maiden and tries to seduce Rāma's younger brother. In stanza 4.31d, we learn that "her fingers, glowing red, are as sharp as porcupine quills" (jarijinyānuji landak ujwalābāì). The connection between the red colour and blood is also obvious in stanza 24.123, in which the porcupine's remarkable red-coloured quill tips are introduced as a simile for soldiers badly wounded by arrows: it is even possible that the poet envisaged the sharp red nails of Sürpanakhā as the Arrows of Kāma.

\section{Pangolin: good to eat or good for thought?}

At another place in the Kakawin Rämāyaṇa, in stanza 124.123, the porcupine is again mentioned alongside the pangolin as they visit the restored pleasure garden, that is now the property of the just Wibhīsana. Both these suitably armored figures now seem to cooperate in protecting the garden:

saṇdin laṇdak surākṣāmawa panah arasuk taì tingilin arin̈ ${ }^{32}$

$[\ldots]$ the porcupine as a good guard was carrying his bow and arrows, ${ }^{33}$ and the pangolin was wearing his coat of mail at his ease.

However, at the end of the story the pangolin and porcupine seem to have met different fates. The last passage in which the pangolin and porcupine figure with one another is found in sarga 26, the last sarga of the Kakawin Rāmāyaṇa, that has often been considered - without offering solid evidence a later addition to the text. Porcupine meat is served at the banquet organized by Rāma on the occasion of his coronation in Ayodhyā, and its taste is likened

32. Kakawin Rāmāyaṇa 24.123d. Old Javanese text taken from Van der Molen (2015: 545).

33. In Old Javanese, panah denotes both the bow and its arrows; although in the passage quoted above panah is used as a metaphor for porcupine quills, because the porcupine is represented as a warrior/soldier on duty I render panah as "bow and arrows." 
to that of pangolin. The chef Bhandira, who seems to have prepared the menu, tempts his guests by listing all kinds of dishes served; the bush-meat of the porcupine is presented as a delicacy worth waiting for patiently:

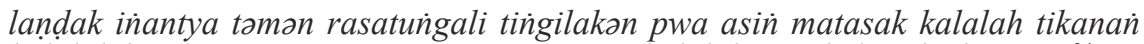
kalalah katəke sira wānarawīra warəgg i rasākalalah nira kāla nikā harəpan ${ }^{34}$

The porcupine should be awaited, truly of the same taste as the pangolin - Now, make haste with everything that is already cooked, before what is impatiently desired comes! Satisfying their desire, heroic simian warriors were impatiently awaiting what was to come.

The passage is, in fact, not entirely clear and can be interpreted in two different ways: either that pangolin figures on the menu, or it is only the taste of pangolin meat that is mentioned. I consider the second possibility the more plausible, as is reflected in my translation above. Totton (2011: 16), based on the translation of the text by Soewito Santoso (1980), is convinced that "Pangolins (...) are (...) served up as part of the celebratory menu when Rama eventually is crowned at Ayodhya." My reading of the text, following Robson (2015), suggests that it is only porcupine that is explicitly listed as an item on menu. Nevertheless, it is clear from Bhandira's speech that the taste of the pangolin meat, too, was known to the guests. In fact, pangolins seem to have been widely eaten in ancient Java, and their flesh did not have to be avoided by some religious groups: the Old Javanese Wratiśäsana, a code of behavior prescribed for religious persons that was compiled after $1300 \mathrm{CE}$, actually lists both porcupine (landak) and pangolin (tingilin) among the animals permitted to be consumed by Śaiwa Siddhānta ascetics. ${ }^{35}$ In my view, the passage in the Kakawin Ràmāyana quoted above seems to imply that porcupine was served as a substitute for pangolin, that, although probably a well-known delicacy in Java, for some reason was considered taboo for consumption at a royal feast. We know from a detailed description in the Deśawarnana, a text composed in 1365 CE by Mpu Prapañca, that few sources of meat protein were prohibited to the lower levels of ancient Javanese society for consumption, and the reason pangolin is avoided in the Kakawin Rāmāyana must be looked elsewhere than in the "Hindu" dietary proscriptions. In my view, it was the symbolic aspect of the pangolin as a "consumer" of rākșasic śakti that forced the author of the text to avoid listing of pangolin as an item on menu. Therefore, the chef Bhandira offers the simian soldiers only porcupine - another bush-meat popular with Javanese peasants, tantalizing them with the claim that its meat is "truly of

34. Kakawin Rāmāyaṇa 26.25. Old Javanese text taken from Van der Molen (2015: 609).

35. Wratiśäsana $08 \mathrm{j}$. The text was composed after $1300 \mathrm{CE}$ as it lists a type of distilled alcoholic drink denoted tampo. Distillation of alcohol was unknown in Java before the late 13 th century CE, as I demonstrate in my new book on alcohol in pre-Islamic Java (Jákl forthcoming). 
the same taste as the pangolin." The passage provides early evidence that pangolins and porcupines were known as food sources in pre-modern Java. Alhough pangolins and porcupines were traditionally consumed in many parts of Southeast Asia, including Java and Vietnam (Woods and Kilpatrick 2005), there is actually little ancient evidence testifying to this practice. The passage quoted above clearly reflects the fact that both animals were actively hunted for meat in Java of the 9th century CE when the Kakawin Ramanyana was composed, but that in the courtly environment the status of the pangolin as a protective animal differed markedly from that of the porcupine.

\section{Conclusion}

In ancient Java, the Sunda pangolin was a symbolically loaded animal. Although mentions of pangolin are rare in Old Javanese literature, the pangolin figures prominently in the Kakawin Rāmāyana, a court poem composed between the second half of the 9th and the first quarter of the $10^{\text {th }}$ century CE. In the three passages out of the four in which a pangolin figures, we find it alongside another conspicuous Javanese mammal: the porcupine. While the porcupine is depicted as promiscuous and tricky, the pangolin seems to have enjoyed a high status in the Javanese (court) imaginaire. I have argued that its unique diet based on ants and termites - insects representing adharma and demonic qualities in pre-Islamic Java - made the pangolin a powerful "consumer" of demonic śakti - and hence an apotropaic animal. This is, in my view, also the reason a very large pangolin was placed as an offering in a man-made shaft beneath Canḍi Nandi in the Prambanan temple complex, at a depth of six metres. Interestingly, this is also the maximum depth to which pangolins burrow in nature. The pangolin was interred in Candi Nandi alongside the remains of one or more porcupines. I have argued that the natural characteristics of both animals - the scaly skin of the pangolin and sharp quills of the porcupine - were responsible for the fact that, in the Kakawin Rāmāyana, a text that reads as an allegory of political power in Java of the 9th century CE, the pangolin and porcupine were perceived as military figures protecting the pleasure garden of Rāwana in Lankā. When the garden was destroyed by Hanumān, and Rāwana was killed in an ensuing battle, the animals - allegorically representing Rāwaña's court, especially his warriors were left without their lord. As a consequence, some of them fled away into hiding (predatory birds representing Rāwaṇa's warlords, the tandas), while others were converted under the rule of wise and just Wibhīsana, and pledged their loyalty to the new order. Still other military figures, represented in the text by the porcupine, were captured and killed: in stanza 26.25, porcupine meat is served at the royal feast organized in Ayodhyā by Rāma, and fed as a delicacy to the simian soldiers, the monkey troops who helped Wibhișana conquer Lankā. The fate of the pangolin, however, seems to be entirely unique: considered an apotropaic animal by rulers of both dharma and adharma, the 
pangolin simply moved from the ruins of Rāwạ̣a's royal garden in Lañkā to a newly laid out one in Lankapura, without undergoing any 'spiritual change' or a change in its status.

\section{Bibliography}

Bernet Kempers, A.J. 1978. Herstel in Eigen Waarde. Monumentenzorg in Indonesië. Amsterdam: Walberg.

Bopearachchi, Osmund. 2006. The Pleasure Gardens of Sigiriya: A New Approach. Colombo: Godage Book Emporium.

Cammerloher, H. 1934. "De op de Boroboedoer Afgebeelde Plantenwereld," De Tropische Natuur 198-224.

Charney, Michael. 2004. Southeast Asian Warfare. Leiden: Brill.

Cooray, Nilan. 2012. The Sigiriya Royal Gardens; Analysis of the Landscape Architectonic Composition. Delft: Technical University.

Degroot, Véronique, M.Y.. 2006. "The Archaeological Remains of Ratu Boko: From Sri Lankan Buddhism to Hinduism," Indonesia and the Malay World 34(98): 55-74.

Goldman, Robert P. and Sally J. Sutherland Goldman. 2007. The Rāmāyaṇa of Vālmīki. An epic of ancient India, volume V: Sundarakānda; Introduction, translation and annotation. Delhi: Motilal Banarsidas.

Griffiths, Arlo. 2011. "Imagine Lankkapura at Prambanan," in: A. Acri, H. Creese \& A. Griffiths (eds.), From Lañkā Eastwards: The Rāmāyana in the Literature and Visual Arts of Indonesia. Leiden: KITLV Press, pp. 133-148.

Griffiths, Arlo. 2013. "The Problem of the Ancient Name Java and the Role of Satyavarman in Southeast Asian International Relations Around the Turn of the Ninth Century CE," Archipel 85: 133-148.

Hiltebeitel, A. 2001. Rethinking the Mahäbhārata; A Reader's Guide to the Education of the Dharma King. Chicago and London: The University of Chicago Press.

Hooykaas, C. 1958. "The Paradise on Earth in Lěngkā (OJR XXIV. 87-126)," Bijdragen tot de Taal-, Land- en Volkenkunde 114(3): 265-91.

Jákl, J. 2012. "Swarming ants and their kin in the Old Javanese kakawin literature," Pandanus 12: 47-63.

Jákl, Jiří. 2015. "Sugar palms and celestial nymphs in Old Javanese kakavin poetry: erotic and martial symbolism of the literary motif," Pandanus 15(1): 89-119.

Jákl, Jiří. forthcoming. Alcohol in Early Java: Its Social and Cultural Significance. Leiden: Brill.

Léger, Daniel. 1979. “A propos d'une cuirasse en peau de pangolin conservée au musée de l'Homme de Paris"”, Archipel 17: 35-41.

McHugh, James. 2012a. "The Disputed Civets and the Complexion of the God: Secretions and History in India," Journal of the American Oriental Society 132(2): 245-73.

McHugh, James. 2012b. Sandalwood and Carrion: Smell in Indian Religion and Culture. New York: Oxford University Press.

Miksic, John N. and Slamet Pinardi. 2015. Kraton Ratu Boko: A Javanese Site of Enigmatic Beauty. Yogyakarta: P.T. Taman Wisata Borobudur dan Prambanan.

Molen, Willem van der. 2015. Rāmāyana. The Story of Rāma and Sìtā in Old Javanese. Romanized Edition. Tokyo: Research Institute for Languages and Cultures of Asia and Africa, Tokyo University of Foreign Studies.

Perret Daniel, et al. Histoire de Barus, Sumatra, III. Regards sur une place marchande de l'océan indien (XIIe - milieu du XVIIe s.). Paris : Archipel - EFEO, 2009.

Quaritch Wales, H.G. 1952. Ancient South-East Asian Warfare. London: Bernard Quaritch. 
Robson, Stuart. 2015. Old Javanese Rāmāyana. A New English Translation with an Introduction and Notes. Tokyo: Research Institute for Languages and Cultures of Asia and Africa, Tokyo University of Foreign Studies.

Robson, S.O. and Singgih Wibisono. 2002. Javanese-English Dictionary. Hong KongSingapore, Periplus Editions (HK).

Schlitter, D.A. 2005. "Order Pholidota," in: Wilson, D.E. and Reader, D.M., Mammal Species of the World: A Taxonomic and Geographic Reference. Baltimore: John Hopkins University, pp. 530-532.

Simmons, N.B. 2005. "Order Chiroptera," in: Wilson, D.E. and Reader, D.M., Mammal Species of the World: A Taxonomic and Geographic Reference. Baltimore: John Hopkins University, pp. 345-346.

Santoso, Soewito. 1980. Ramayana kakawin. New Delhi: Mrs. Sharada Rani, Hauzkhas Enclave.

Sundberg, Jeffrey. 2004. "The wilderness monks of the Abhayagirivihāra and the origins of Sino-Javanese esoteric Buddhism," Bijdragen tot de Taal-, Land- en Volkenkunde 160(1): 95-123.

Totton, Mary-Louise. 2011. "The Pangolin. A multivalent memento in Indonesian art," Indonesia and the Malay World 39(113): 7-28.

Woods, C.A. and Kilpatrick, C.W. 2005. "Hystricognathi," in: Wilson, D.E. and Reader, D.M., Mammal Species of the World: A Taxonomic and Geographic Reference. Baltimore: John Hopkins University, pp. 1538-1600.

Wozencraft, W.C. 2005. "Order Carnivora," in: Wilson, D.E. and Reader, D.M., Mammal Species of the World: A Taxonomic and Geographic Reference. Baltimore: John Hopkins University, pp. 532-628.

Zoetmulder, P.J. 1974. Kalangwan: A survey of Old Javanese literature. The Hague, Nijhoff.

Zoetmulder, P.J. 1982. Old Javanese-English dictionary. With the collaboration of S.O. Robson. Two volumes. 's-Gravenhave, Nijhoff. 
